\title{
The utilization of the response surface methodology for the optimization of cultivation medium and growth parameters in the cultivation of the yeast strain $S$. cerevisiae 3.20 on ethanol
}

\author{
O. Popa ${ }^{\star}$, Narcisa Babeanu, A. Vamanu and E. Vamanu \\ Faculty of Biotechnology, University of Agronomical Sciences and Veterinary Medicine, 59 Marasti Bld., Bucharest - \\ 011464 Romania. \\ Accepted 8 November, 2007

\begin{abstract}
A mutant strain of the yeast Saccharomyces cerevisiae growing on ethanol as single source of carbon and energy was used in optimization experiments at laboratory and micropilot scale, following the surface response methodology. The cultivation medium optimization was performed on the basis of maximization of dry cell weight and the process parameters optimization on the basis of substrate yield maximization.
\end{abstract}

Key words: Ethanol, optimization, response surface methodology, yeast.

\section{INTRODUCTION}

The use of yeast as therapeutic agent has been well known since antiquity. But only at the end of nineteenth century, the brewing yeast Saccharomyces cerevisiae was first published in a pharmacopeia. In 1899 Brocq was the first scientist who studied the action of the yeast $S$. cerevisiae in the cutaneous diseases, starting from the observation that the workers from the beer plants were not affected by furunculosis.

Later studies made possible the administration of Saccharomyces yeast in the treatment of B avitaminosis, colitis, acute diarrhea and diabetes (Hochter, 1990; Offenbacher et al., 1985; Massot et al., 1984) due to its high content in the vitamins $B$ group. The viable yeast biomass is also used as an additional source for proteins and vitamins in malnutrition and denutrition cases (Segal, 1991). For all these reasons, there is a growing interest in the cultivation of yeast of genera Saccharomyces and Candida, advised by FAO for human use, on substrates also accepted for human use.

The attractiveness of ethanol as a substrate for micro-

*Corresponding author. E-mail: ovid_popa@yahoo.com. Tel: 0040723693654 . Fax: 0040213203752. bial cultivation comes from its availability as a petrochemical pure feedstock and from the acceptance of the final product grown on this substrate as an edible protein. Furthermore the standard quality of the substrate, in contrast to molasses variability, guarantees for the constant quality of the product.

Several yeast strains are cited by the literature for their ability to grow on ethanol as the single source of carbon and energy: S. cerevisiae (Keulers et al., 1996; Wasungu and Simard, 1982; Mor and Fiechter, 1968a), Candida utilis (Peskova, 1998; Paca and Votruba, 1994; Votruba and Paca, 1992; Prior et al., 1980; Watteeuw et al., 1979), Torulopsis ethanolitolerans (Potucek, 1989), Pichia pastoris (Duff et al., 1989) and Candida krusei (Kilian et al., 1981). Several papers studying the cultivation conditions for yeast growing on ethanol as well as the influence of different process parameters on yeasts' performance were reported (Kilian et al., 1981; Prokop et al., 1978; Eroshin et al., 1976; Mor and Fiechter, 1968b).

This paper aims to optimize the composition of the growth medium and the cultivation parameters of the bioprocess for obtaining biomass on ethanol with the strain $S$. cerevisiae 3.20 , using the response surface methodology. Different studies presented in the literature on the ethanol tolerance of yeast (Norton et al., 1995; 
Table 1. The limits and coding of medium components (independent variables).

\begin{tabular}{|c|c|c|c|c|c|c|c|}
\hline \multirow[b]{2}{*}{ Variable } & \multirow[b]{2}{*}{ Code } & \multicolumn{5}{|c|}{ Variable level } & \multirow{2}{*}{$\begin{array}{c}\text { Range } \\
\Delta=3.3634 \\
\end{array}$} \\
\hline & & -1.6817 & -1 & 0 & 1 & +1.6817 & \\
\hline $\mathrm{KH}_{2} \mathrm{PO}_{4}$ & $x_{1}$ & 188 & 800 & 1700 & 2600 & 3213 & $3025 \mathrm{mg} / \mathrm{l}$ \\
\hline $\mathrm{MgSO}_{4} \cdot 7 \mathrm{H}_{2} \mathrm{O}$ & $x_{2}$ & 114 & 270 & 500 & 730 & 886 & 772 mg/l \\
\hline Corn steep liquor & $x_{3}$ & 0.3 & 1 & 2 & 3 & 3.7 & $3.4 \mathrm{~g} / \mathrm{l}$ \\
\hline
\end{tabular}

D'Amore et al., 1990) made us determined to use yeast strain resistant to higher ethanol concentrations.

The response surface methodology is a three-factorial design which provides the relationship between one or more measured dependent responses and a number of input (independent) factors (Kafarov, 1976; Box and Hunter, 1957). The response surface method has some advantages that include a smaller number of experiments, suitability for multiple factor experiments, search for relativity between multiple factor experiments and finding of the most suitable correlation and forecast response (Sayyad et al., 2007; Shieh et al., 2003). This facilitates the determination of the optimum values for the factors under investigation and the prediction of a response under optimized conditions (Smigelschi and Woinarovschy, 1978).

\section{MATERIALS AND METHODS}

\section{Materials}

Ethanol, kalium dihydrogen phosphate, magnesium sulphate and diammonium sulphate are all purchased from CHIMO-PAR Bucharest. Yeast extract, peptone, glucose and malt extract were obtained from SIGMA.

\section{Strain, media and cultivation conditions}

The used yeast strain S. cerevisiae 3.20 is a UV mutant from the Collection of Industrial Microorganisms of the National Institute for Chemical Pharmaceutical $\mathrm{R}$ and $\mathrm{D}$ Bucharest, registered WFCC 232. The selection criterion for mutagenesis was the resistance to acetaldehyde.

The composition ( $\mathrm{w} / \mathrm{v})$ of the inoculum medium is: yeast extract $1 \%$, peptone $1 \%$, malt extract $1 \%$, and glucose $1 \%$. Equal aliquots of ethanol were added at $0,12,24$ and $36 \mathrm{~h}$, so the total concentration of the added ethanol was $2 \%(\mathrm{v} / \mathrm{v}) . \mathrm{pH}$ was adjusted at $4.0-4.5$ with $12.5 \%(\mathrm{v} / \mathrm{v}) \mathrm{NH}_{4} \mathrm{OH}$ solution at every $12 \mathrm{~h}$.

The composition ( $\mathrm{w} / \mathrm{v})$ of the cultivation medium for the second stage of the bioprocess is: $\mathrm{KH}_{2} \mathrm{PO}_{4} 0.10 \%,\left(\mathrm{NH}_{4}\right)_{2} \mathrm{SO}_{4} 0.20 \%$, corn steep liquor (50\% D.C.W.) $0.20 \%$ and $\mathrm{MgSO}_{4} \cdot 7 \mathrm{H}_{2} \mathrm{O} 0.05 \%$. Equal aliquots of ethanol were added at $0,12,20$ and $28 \mathrm{~h}$, so the total concentration of added ethanol was $2 \%(\mathrm{v} / \mathrm{v})$. The $\mathrm{pH}$ was adjusted at $4.0-4.5$ with $12.5 \%(\mathrm{v} / \mathrm{v}) \mathrm{NH}_{4} \mathrm{OH}$ solution before each addition of the ethanol.

The inoculum phase and the second cultivation one (first lasting $48 \mathrm{~h}$ and the second one, $36 \mathrm{~h}$ ) were performed at laboratory scale, in $500 \mathrm{ml}$ Erlenmeyer flasks, with $100 \mathrm{ml}$ medium, closed with cotton stoppers, on a rotary shaker $(240 \mathrm{rpm})$ at $28 \pm 0.5^{\circ} \mathrm{C}$. The inoculum culture was transferred $10 \%(\mathrm{v} / \mathrm{v})$ to the flasks of the second generation and the bioprocess continued for $36 \mathrm{~h}$ in the same conditions described above.

The assays for the determination of the optimum composition of the fermentation medium by the response surface method were performed during the second stage of the cultivation of the yeast $S$. cerevisiae 3.20.

The next stage experiments in order to establish the optimum values for some cultivation parameters $(\mathrm{pH}, \mathrm{T})$ were performed in a New Brunswick bench scale bioreactor with 8 I working volume (geometric volume $=12 \mathrm{I})$, inoculated with $10 \%(\mathrm{v} / \mathrm{v})$ second generation culture, obtained in the laboratory experiments. The bioreactor was equipped with automatic control of temperature, $\mathrm{pH}$, air admission, agitation speed, the concentrations of dissolved oxygen and carbon dioxide in the exhausted gases.

The medium composition was the same as determined in the laboratory phase experiments. The $\mathrm{pH}$ was maintained between 4.0 - 4.2 by automatic correction with a $12.5 \%(\mathrm{v} / \mathrm{v}) \mathrm{NH}_{4} \mathrm{OH}$ solution.

The addition of ethanol was automatically performed in order to maintain the dissolved oxygen concentration in the medium during the fermentation greater than $10 \%$ of the saturation value.

\section{Analytical methods}

The evolution of yeast cell development during the cultivation was evaluated by determining the optical density $(\lambda=570 \mathrm{~nm})$ correlated to the dry cell weight, each value being the mean value of two determinations.

Ethanol was determined by gas chromatography, using the external standard method, from the supernatant samples resulted after the centrifugation of measured volumes of fermentation broth. Analyses were performed on a FID Carlo-Erba FRACTOVAP 4200 gas chromatograph, using a glass column $(1,500 \times 24 \mathrm{~mm})$, packed with 80 - 100 mesh Porapack $Q$. The nitrogen flow was $50 \mathrm{ml} / \mathrm{min}$, temperature $200^{\circ} \mathrm{C}$.

\section{RESULTS AND DISCUSSION}

In order to quantify the influence of the cultivation medium components on the biomass concentration, a central composite design was used, by which we studied the influence of three factors in 17 runs. The design is to be run in a single block. To provide protection against the effects of lurking variables, the order of experiments has been fully randomized.

As independent variables, the concentrations of potassium dihydrogen phosphate, magnesium sulphate and corn steep liquor were selected. The range of variation and the codification of the variables are presented in Table 1, and the experimental matrix is given in Table 2. 


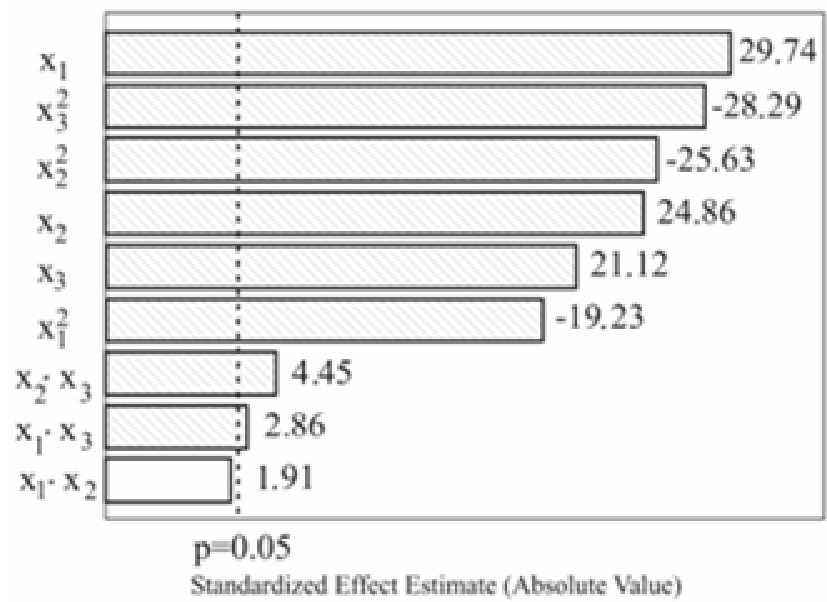

Figure 1. Pareto chart of standardized effects.

In order to analyze the experimental data, a secondorder regression equation was proposed:

$Y=b_{0}+b_{1} x_{1}+b_{2} x_{2}+b_{3} x_{3}+b_{12} x_{12}+b_{13} x_{13}+b_{23} x_{23}+$ $b_{11} x_{1}^{2}+b_{22} x_{2}^{2}+b_{33} x_{3}^{2}$

Where $Y$ - Normalized dry cell weight; $x_{1}, x_{2}, x_{3}$ - the independent variables; $b_{0}, b_{1}, \ldots b_{33}$ - the coefficients of the regression equation.

The Pareto chart (Figure 1) shows each of the estimated effects, interactions and the standard error of each of the effects, which measures their sampling error. In the experimental design the Pareto chart is a Frequency Histogram that shows the amount of influence each factor has on the response in decreasing order. Because the interaction between $x_{1}$ and $x_{2}$ has no statistical significance, the term $x_{1} \cdot x_{2}$ will be cancelled from the final equation:

$\mathrm{Y}=95.9538+17.9097 \cdot \mathrm{x}_{1}+14.9741 \cdot \mathrm{x}_{2}+12.7175 \cdot \mathrm{x}_{3}+$ $2.2500 \cdot x_{13}+3.5000 \cdot x_{23}-12.7455 x_{1}^{2}-16.9881 \cdot x_{2}^{2}-$ $18.7559 \cdot x_{3}{ }^{2}$

Figure 1 shows that the variable $x_{1}$ has the greatest influence on $Y$, followed by $x_{3}^{2}$ and $x_{2}^{2}$. The great numerical values for the quadratic terms justify the selection of the response surface method in the experimental design. The results presented in Table 3 showed an excellent correlation between the calculated and the experimental values.

Plot of the response surfaces for $Y=f\left(x_{1}, x_{2}, 0.5\right), f\left(x_{1}\right.$, $\left.0.5, x_{3}\right), f\left(0.5, x_{2}, x_{3}\right)$ showed a global maximum situated in the area $x_{1}, x_{2}, x_{3} \in(0,1)$, as it can be observed in Figures 2, 3 and 4 . The maximum value for $Y$ was obtained using the gradient method with the start point (1, 1 , and 1). The optimal values of parameters for $Y_{\max }$ $=108.94$ are: $x_{1}=0.74, x_{2}=0.48, x_{3}=0.43$. These normalized values correspond to the real optimal values of the
Table 2. The experimental matrix for rotatable central composite design: $\left(2^{3}+\right.$ star $)$.

\begin{tabular}{|c|c|c|c|c|}
\hline Block & $\mathbf{X}_{1}$ & $\mathbf{X}_{\mathbf{2}}$ & $\mathbf{X}_{3}$ & $\mathbf{Y}$ \\
\hline 1 & 0 & -1.68179 & 0 & 20 \\
1 & 1 & 1 & -1 & 62 \\
1 & 0 & 0 & 1.68179 & 65 \\
1 & -1 & -1 & 1 & 25 \\
1 & 0 & 0 & -1.68179 & 20 \\
1 & 0 & 0 & 0 & 95 \\
1 & 1 & -1 & -1 & 40 \\
1 & -1 & 1 & 1 & 55 \\
1 & 0 & 0 & 0 & 97 \\
1 & 1.68179 & 0 & 0 & 90 \\
1 & -1 & 1 & -1 & 30 \\
1 & -1 & -1 & -1 & 10 \\
1 & 1 & -1 & 1 & 60 \\
1 & 0 & 1.68179 & 0 & 75 \\
1 & -1.68179 & 0 & 0 & 29 \\
1 & 1 & 1 & 1 & 100 \\
1 & 0 & 0 & 0 & 96 \\
\hline
\end{tabular}

medium's components presented in Table 4.

The next step in our experiments was the determination of the optimum values for $\mathrm{pH}$ and temperature. The experiments were performed in a New Brunswick bioreactor, using as inoculum $(10 \% \mathrm{v} / \mathrm{v})$ the culture obtained in the second laboratory phase, having the parameters described in Table 5.

Several cultivations were run in the bioreactor in the conditions described above. All were stopped at $24 \mathrm{~h}$, at a final DCW around $35 \mathrm{~g} / \mathrm{l}$, when a severe decrease in the ethanol consumption rate was observed. The specific growth rate for the exponential phase $(8-20 \mathrm{~h})$ was $0.157 \mathrm{~h}^{-1}$, with a maximum of $0.165 \mathrm{~h}^{-1}$ between $16-20 \mathrm{~h}$. Under these conditions the total substrate yield was 0.66 [g biomass/g ethanol].

The experiments for the optimization of the cultivation parameters $(\mathrm{pH}, \mathrm{T})$ were performed in the conditions described above. We used a central composite design $\left(2^{2}\right.$ + star) to study the effects of the two factors on the substrate yield, in 10 runs. The order of the experiments was completely randomized. The codification of the variables is presented in Table 6 . The experimental matrix is shown in Table 7.

The value 1 corresponds to a substrate yield of 0.66 $[\mathrm{g} / \mathrm{g}]$. The dependence $\mathrm{Z}(\mathrm{pH}, \mathrm{T})$ is described by a second-order regression equation:

$Z=0.983+0.314 x_{4}-0.079 x_{5}-0.212 x_{4}^{2}-0.0025 x_{4} x_{5}-$ $0.195 \mathrm{x}_{5}^{2}$

Drawing a new Pareto chart for this dependence (not shown) the term $x_{4} \cdot x_{5}$ was removed from the final equation as it had no statistical significance and the 
Table 3. Comparison between experimental and calculated data for $Y$.

\begin{tabular}{|c|c|c|c|c|}
\hline Row & $\begin{array}{c}\text { Experimental } \\
\text { value }\end{array}$ & Fitted value & $\begin{array}{c}\text { Lower 95.0\% } \\
\text { CL for mean }\end{array}$ & $\begin{array}{c}\text { Upper 95.0\% } \\
\text { CL for mean }\end{array}$ \\
\hline 1 & 10 & 7.62 & 3.25 & 11.98 \\
2 & 20 & 21.52 & 16.17 .90 & 26.13 \\
3 & 100 & 98.82 & 94.95 & 103.18 \\
4 & 55 & 58.50 & 54.13 & 62.86 \\
5 & 29 & 29.78 & 25.17 & 34.40 \\
6 & 95 & 95.95 & 92.54 & 99.36 \\
7 & 65 & 64.29 & 59.68 & 68.90 \\
8 & 30 & 30.56 & 26.19 & 34.91 \\
9 & 97 & 95.95 & 92.54 & 99.36 \\
10 & 62 & 61.88 & 57.51 & 66.25 \\
11 & 20 & 22.72 & 18.11 & 27.33 \\
12 & 40 & 38.93 & 34.56 & 43.30 \\
13 & 25 & 21.55 & 17.18 & 25.92 \\
14 & 60 & 61.87 & 57.50 & 66.24 \\
15 & 75 & 73.09 & 68.47 & 77.70 \\
16 & 90 & 90.02 & 85.41 & 94.64 \\
17 & 96 & 95.95 & 92.54 & 99.36 \\
\hline
\end{tabular}

Table 4. The values of the independent variables leading to the maximum biomass concentration.

\begin{tabular}{|c|c|c|c|}
\hline Parameter & Component & Normalized values & True values \\
\hline $\mathrm{x}_{1}$ & $\mathrm{KH}_{2} \mathrm{PO}_{4}$ & 0.74 & $2366[\mathrm{mg} / \mathrm{l}]$ \\
$\mathrm{x}_{2}$ & $\mathrm{MgSO}_{4} \cdot 7 \mathrm{H}_{2} \mathrm{O}$ & 0.48 & $610[\mathrm{mg} / \mathrm{l}]$ \\
$\mathrm{x}_{3}$ & Corn steep liquor & 0.43 & $2.43[\mathrm{~g} / \mathrm{l}]$ \\
$\mathrm{Y}$ & Dry cell weight & 109 & $10.7[\mathrm{~g} / \mathrm{l}]$ \\
\hline
\end{tabular}

Table 5. The characteristics of the standardized inoculum used for the bioreactor cultivation.

\begin{tabular}{|l|c|}
\hline \multicolumn{1}{|c|}{ Parameter } & Value \\
\hline Strain & S. cerevisiae 3.20 \\
Time of cultivation $[\mathrm{h}]$ & 36 \\
Temperature $\left[{ }^{\circ} \mathrm{C}\right]$ & $28 \pm 0.5$ \\
$\mathrm{pH}$ & $4.0 \pm 0.2$ \\
Culture medium & Previously determined \\
Working Volume $[\mathrm{ml}]$ & $\mathrm{Vu} / \mathrm{Vg}=100 / 500$ \\
Ethanol & $2 \%$ \\
Dry cell weight $[\mathrm{g} / \mathrm{l}]$ & 10.7 \\
$\mathrm{M}\left[\mathrm{h}^{-1}\right]$ & 0.135 \\
\hline
\end{tabular}

equation became:

$Z=0.983+0.314 x_{4}-0.079 x_{5}-0.212 x_{4}^{2}-0.195 x_{5}^{2}$

The response surface and contour plots for $\mathrm{Z}=\mathrm{f}(\mathrm{pH}$, $\mathrm{T})$ are presented in Figure 5. The coordinates of maxim were $(+0.76,-0.203)$. The maximum values obtained for $\mathrm{x}_{4}$ and $\mathrm{x}_{5}$ correspond to the real values: $\mathrm{pH}=4.76, \mathrm{~T}=$ $27.5^{\circ} \mathrm{C}$. The theoretical $Z_{\max }$ obtained by applying the statistical method was 1.11 .

In order to verify the accuracy of the theoretical predictions, three other cultivations were performed in the bioreactor, keeping all the parameters described above at the mentioned values, except for the $\mathrm{pH}$ and the temperature. The temperature was kept between 27.4 $27.6^{\circ} \mathrm{C}$, and the $\mathrm{pH}$ between 4.65 and 4.8 . In these conditions the mean value obtained in the three runs for the substrate yield was $0.61 \mathrm{~g}$ ethanol/ $\mathrm{g}$ biomass, corresponding to an experimental value for $Z_{\max }$ of 1.08 .

\section{Conclusions}

The mutant strain $S$. cerevisiae 3.20 was used both in laboratory and micropilot experiments to determine the optimal composition of the growth medium and also the optimal values for the process parameters $\mathrm{pH}$ and temperature. In both sets of experiments, the response 

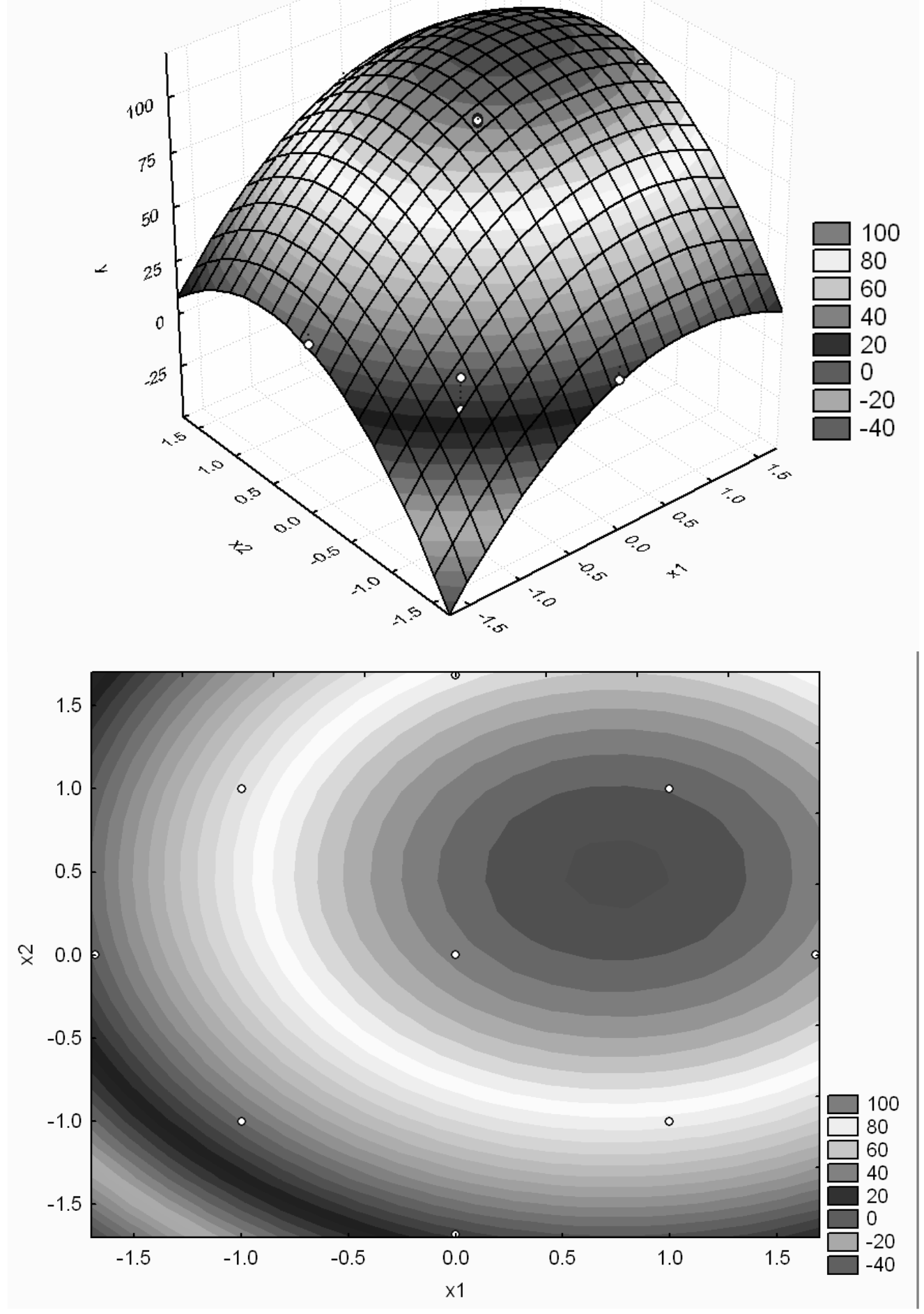

Figure 2. Response surface and contour plots $f\left(x_{1}, x_{2}, 0.5\right)$.

Table 6. The codification of the model's variables.

\begin{tabular}{|l|c|c|c|c|c|c|c|}
\hline \multicolumn{1}{|c|}{ Variable } & Code & \multicolumn{5}{c|}{ Variable levels } & Range \\
\hline & & -1.414 & -1 & 0 & 1 & 1.414 & 2.828 \\
$\mathrm{pH}$ & $\mathrm{X}_{4}$ & 2.6 & 3.0 & 4.0 & 5.0 & 5.4 & 2.8 \\
Temperature & $\mathrm{X}_{5}$ & 24.5 & 25.5 & 28 & 30.5 & 31.5 & 7 \\
\hline
\end{tabular}




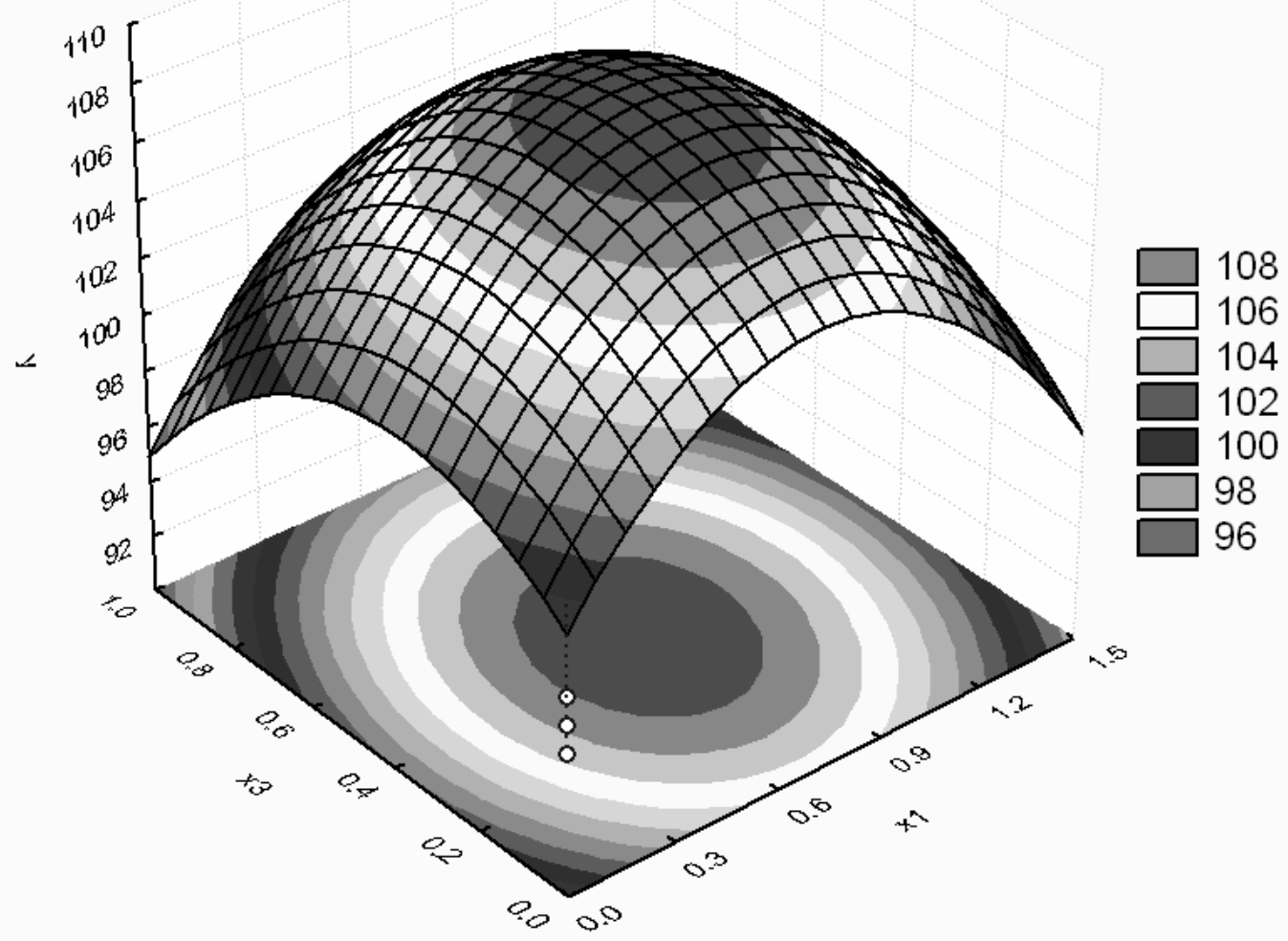

Figure 3. Response surface and contour plots for $f\left(x_{1}, 0.5, x_{3}\right)$.

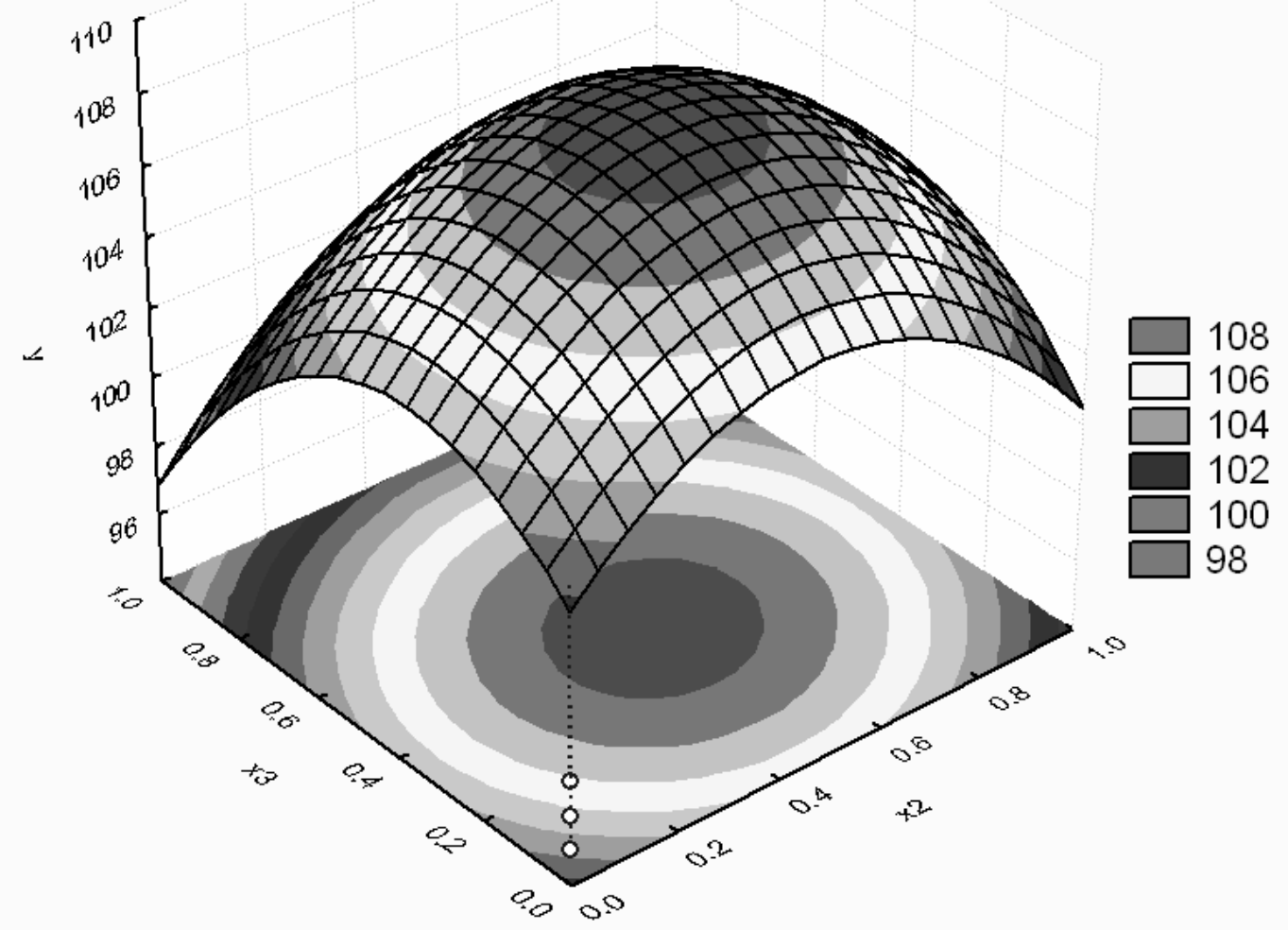

Figure 4. Response surface and contour plots for $f\left(0.5, x_{2}, x_{3}\right)$. 


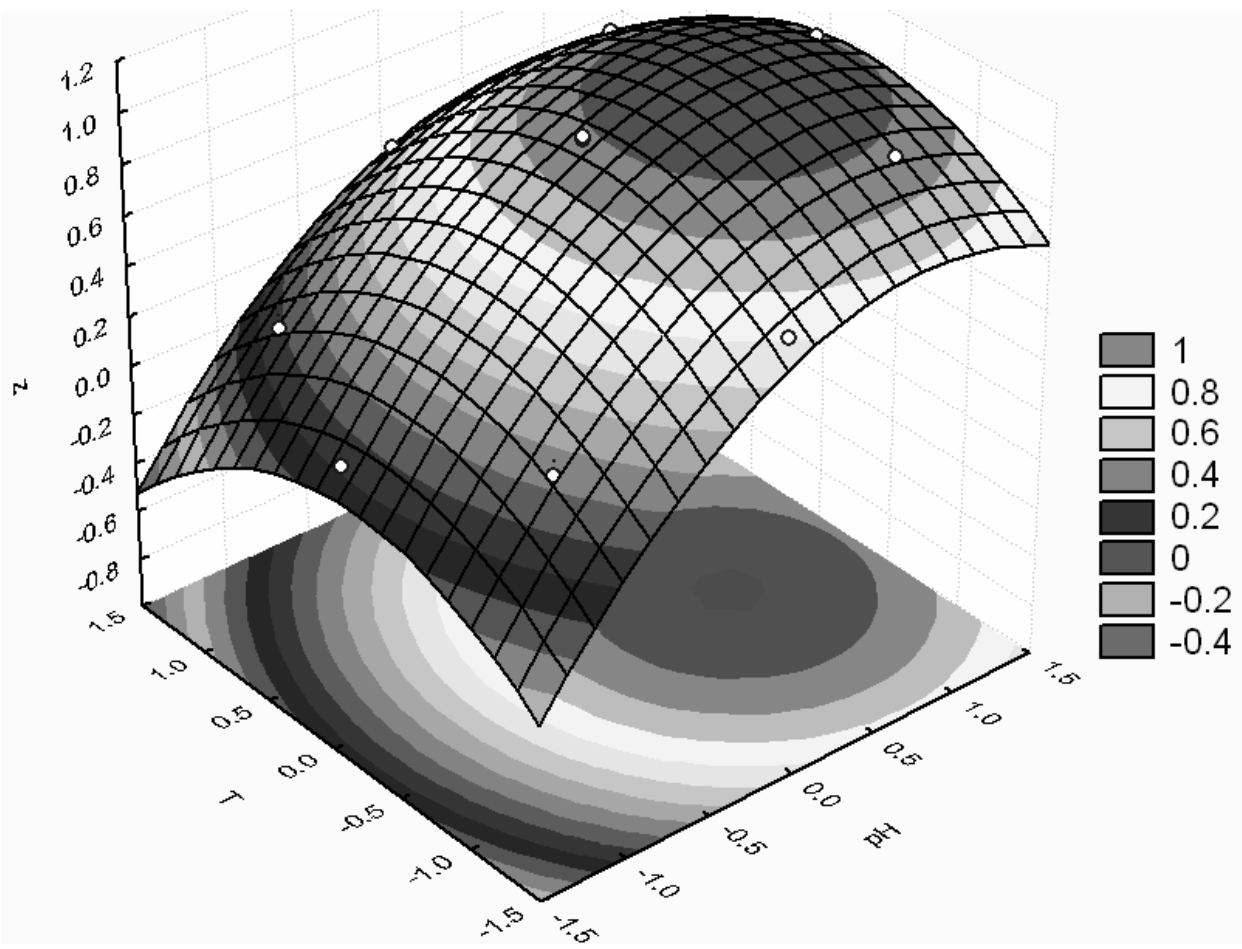

Figure 5. Response surface and contour plots for $Z_{2}=f(p H, T)$.

Table 7. The experimental matrix for the central composite design $\left(2^{2}+\right.$ star $)$.

\begin{tabular}{|c|c|c|c|}
\hline Block & $\mathbf{p H}$ & $\mathbf{T}$ & $\mathbf{Z}$ \\
\hline 1 & 1.414 & 0 & 1 \\
1 & 1 & -1 & 0.97 \\
1 & 0 & -1.414 & 0.71 \\
1 & -1 & 1 & 0.18 \\
1 & 0 & 1.414 & 0.48 \\
1 & -1 & -1 & 0.33 \\
1 & 0 & 0 & 0.98 \\
1 & 1 & 1 & 0.81 \\
1 & -1.414 & 0 & 0.12 \\
1 & 0 & 0 & 0.98 \\
1 & 0 & 0 & 0.99 \\
\hline
\end{tabular}

surface methodology was used. The optimal composition of the growth medium, established by a central composite design $\left(2^{3}+\right.$ star $)$ was: $\mathrm{KH}_{2} \mathrm{PO}_{4^{-}} 2366 \mathrm{mg} / \mathrm{l}$, $\mathrm{MgSO}_{4} \cdot 7 \mathrm{H}_{2} \mathrm{O}-610 \mathrm{mg} / \mathrm{l}$, corn steep liquor $(50 \%$ dry substance) $2.43 \mathrm{~g} / \mathrm{l}$ which yielded to a final dry cell weight of $10.7 \mathrm{~g} / \mathrm{l}$. The optimal values for the cultivation parameters $\mathrm{pH}$ and temperature, determined by a similar experiment were $\mathrm{pH}=4.76$, and $\mathrm{T}=27.5^{\circ} \mathrm{C}$, for which a substrate yield of about $0.6 \mathrm{~g}$ ethanol $/ \mathrm{g}$ biomass was obtained.

\section{ACKNOWLEDGMENT}

Financial support from the Romanian Ministry of Education and Research is gratefully acknowledged.

\section{REFERENCES}

Box GEP, Hunter JS (1957). Multifactor experimental design for exploring response surfaces. Ann. Math. Stat. 28: 195-241.

D'Amore T, Panchal CJ, Russell I, Stewart GG (1990). A study of ethanol tolerance in yeast. Crit. Rev. Biotechnol. 9: 287-304.

Duff SJB, Murray WD, Overend RP (1989). Factors affecting the yeastmediated conversion of ethanol to acetaldehyde in batch reactors. Enzym. Microb. Technol. 11: 770-775.

Eroshin VK, Utkin IS, Ladynichev, SV, Samoylov VV, Kuvshinnikov VD, Skryabin GK (1976). Influence of $\mathrm{pH}$ and temperature on the substrate yield coefficient of yeast growth in a chemostat. Biotechnol. Bioeng. 18: 289-295.

Hochter W (1990). Saccharomyces boulardii in acute adult diarrhea. Eficacity and tolerance of treatment. Physician, Gastroenterology Consulting-Room, Munchener Medizinische Wochenschrift 132: 188192.

Kafarov V (1976). Cybernetic Methods in Chemistry \& Chemical Engineering, MIR Publishers, Moscow.

Keulers M, Suzuki T, Satroutdinov AD, Kuriyama H (1996). Autonomous metabolic oscillation in continuous culture of Saccharomyces cerevisiae grown on ethanol. FEMS Microbiol. Lett. 142: 253-258.

Kilian SG, Prior BA, Lategan PM, Kruger WCJ (1981) Temperatures effects on ethanol and isopropanol utilization by Candida krusei. Biotechnol. Bioeng. 23: 267-275.

Massot J, Sanchez O, Couchy R, Astoin J, Parodi AL (1984). Bacteriopharmacological activity of Saccharomyces boulardii in clindamycininduced colitis in the hamster. Arzneimittelforschung 34: 794-797.

Mor J, Fiechter A (1968a). Continuous cultivation of Saccharomyces cerevisiae. I. Growth on ethanol under steady-state conditions. Biotechnol. Bioeng. 10: 159-176. 
Mor J, Fiechter A (1968b) Continuous cultivation of Saccharomyces cerevisiae. II. Growth on ethanol under transient-state conditions. Biotechnol. Bioeng. 10: 783-803.

Norton S, Watson K, D'Amore T (1995). Ethanol tolerance of immobilized brewers' yeast cells. Appl. Microbiol. Biotechnol. 43: 1824.

Offenbacher EG, Rinko CJ, Pi-Sunyer FX (1985). The effects of inorganic chromium and brewer's yeast on glucose tolerance, plasma lipids, and plasma chromium in elderly subjects. Am. J. Clin. Nutr. 42: 454-457.

Paca J, Votruba J (1994). External conditions influencing ethanol oxidation by resting cells of Candida utilis. Folia Microbiol. 39: 65-70.

Peskova EB, Sharyshev AA, Finogenova TV (1998). The role of mitochondria and peroxisomes in the ethanol oxidation in yeast. Folia Microbiol. 43: 210-211.

Potucek F (1989). Oxygen transfer during batch cultivation in an airlift tower fermentor. Collect. Czech. Chem. Commun. 54: 3213-3219.

Prior B, Kilian S, Lategan P (1980) Growth of Candida utilis on ethanol and isopropanol. Arch. Microbiol. 125: 133-136.

Prokop A, Votruba J, Sobotka M, Panos J (1978). Yeast SCP from ethanol: Measurements, modeling and parameter estimation in batch system. Biotechnol. Bioeng. 20: 1523-1540.

Sayyad SA, Panda BP, Javed S, Ali M (2007). Optimization of nutrient parameters for lovastatin production by Monascus purpureus MTCC 369 under submerged fermentation using responce surface methodology. Appl. Microbiol. Biotechnol. 73: 1054-1058.
Segal B (1991). Drojdiile ca aliment-medicament. In: Anghel I (ed) Biologia si Tehnologia Drojdiilor, vol 2, Editura Tehnica, Bucharest.

Shieh CJ, Liao HF, Lee CC (2003). Optimization of lipase-catalyzed biodiesel by response surface methodology, Bioresour. Technol. 88: 103-106.

Smigelschi O, Woinarovschy A (1978). Optimizarea Proceselor in Industria Chimica, Editura Tehnica, Bucharest.

Votruba J, Paca J (1992). Phenomenological theory of substrateinduced acidification with application to Candida utilis dissimilating ethanol. Folia Microbiol 37: 133-139.

Wasungu K, Simard R (1982). Growth characteristics of baker's yeast in ethanol. Biotechnol. Bioeng. 24: 1125-1134.

Watteeuw CM, Arminger WB, Ristroph DL, Humphrey AE (1979). Production of single cell protein from ethanol by fed-batch process, Biotechnol. Bioeng. 21: 1221-1237. 